\title{
Determination of Humanitarian Aid Depots Location for The Eruption of Mount Merapi Victims
}

\author{
Diana Puspita Sari ${ }^{1}$, Dyah I Rinawati ${ }^{2}$, Naniek U. Handayani ${ }^{3}$, Yusuf Widharto ${ }^{4}$, Adri \\ Dharmesta $^{5}$ \\ \{dpsari.01@gmail.com¹, dyah.ika@gmail.com², naniekh@gmail.com ${ }^{3}$ \} \\ Industrial Enginering Department, Faculty of Engineering, Diponegoro University \\ Jl. Prof Soedarto SH - Tembalang, Semarang ${ }^{12345}$
}

\begin{abstract}
Mount Merapi is one of the most active mountains in Indonesia. The area most affected by Mount Merapi eruption is Sleman Regency. The problem when disaster management is inaccurate fulfilling and delivering the humanitarian aids during the eruption, this is due to a lack of humanitarian aid depot (HAD) that can serve the needs of refugees. This study aims to determine the four HAD locations so able to serve the needs of refugees. Determination of four HAD locations refers to the watershed at the foot of Mount Merapi. There are four areas from west to east which are bordered by river. This study used center of gravity methods to get the best location. The selected HAD location are the Jogokerten for the first area, Huntap Kuwang for the third area, Sindumartani for the fourth area, while for second area used Pusdalops Pakem HAD which has been established previously.
\end{abstract}

Keywords: humanitarian aid depot, center of gravity, eruption, mount merapi.

\section{Introduction}

Disaster management is a key factor that drives the successful implementation of relief efforts [1]. A good disaster management is balanced management in the phases before, during or after a disaster. Natural disaster is an incident that can not be predicted with accurate so that most of the operation of natural disaster scenario handling. Logistics in the sense of disaster management means everything that can be used to meet the basic needs of human life, both food, clothing, boards, and derivatives. The availability of adequate logistics is an absolute requirement because it is directly related to the survival of disaster victims. Humanitarian logistics includes the process of planning, implementing, and controlling the flow and storage of goods and materials that are efficient, cost-effective, and related information, from the point of origin to the point of consumption to reduce people's suffering [2]. Ref. [3] identified key success factors are relevant in humanitarian supply chains. The humanitarian aid supply chain has similarities with the supply chain in ordinary business, but there is a difference that the humanitarian supply chain has a short-term and unstable existence. There is no link between emergency aid and long-term development aid [4].

The study of the location of humanitarian aid warehouses has been done several times with several different models. Ref.[5] designed a multi-criteria decision analysis model to determine the best location for warehouse in disaster logistics in Trabzon, Turkey. Ref.[6] proposed an artificial neural network approach for the location selection problem of the

ICCSET 2018, October 25-26, Kudus, Indonesia

Copyright (C) 2018 EAI

DOI 10.4108/eai.24-10-2018.2280540 
logistics centers. In this study consider the factors such as accessibility, costs, land feasibility, socio-economic and environmental factors as the critical factors in selecting the most suitable location of logistics center. Ref.[7] conducted a facility location survey related to emergency humanitarian logistics based on the type of data modeling and type of problem and to compare the situation before and after a disaster in relation to the location of the facility, such as the location of distribution centers, warehouses, shelters, debris cleaning locations, medical centers. Ref.[8] identified the key factors for selecting humanitarian aid depot (HAD) as criteria in AHP, such as national stability, cost, logistics and location. Ref.[9] designed a scenario of two-stage stochastic evacuation planning model that optimally determines the location of shelters that provide evacuation to nearby shelters and the shortest path to minimize total evacuation time. Ref.[10] introduced a model of the design and humanitarian aid distribution used mathematical integer linear programming to determine the location of humanitarian relief warehouses in Canada. Previous research studies that have been carried out are mostly qualitative, so this study will determine the location of HAD using a quantitative. The method used in this research is center of gravity (cluster analysis)

Geographically Indonesia lies in the encounter area of three major plates of the world namely Eurasia, Pacific, and Indo-Australia, making most of Indonesia into the Pacific Ring of Fire. According to the Geological Disease Investigation and Development Agency (BPPTKG) among all the mountains in Indonesia, Mount Merapi is one of the most active volcanoes since the area of is above the Indo-Australian plate. According to [11] the high activity of Mount Merapi is also influenced by its location which lies in the intersection of two local fault systems stretching in the north-south direction forming the complex of Mount Merapi, Mount Merbabu, and Mount Ungaran, with the west-east. Because the location of Merapi is located in the zone of intersection of the faults that make the way out for magma becomes easier. Mount Merapi erupts periodically since the first major eruption recorded in the year 1006 until the last major eruption in 2010 ago. The 2010 eruption is one of the most explosive eruptions recorded so far. Based on data on the official site of Sleman District Government has an area of 57,482 ha and $48 \%$ of them into the disaster-prone areas of Mount Merapi eruption. The disaster prone areas cover 7 districts namely Cangkringan, Turi, Pakem, Ngaglik, Ngemplak, Sleman, and Tempel with a population of 301,855 people. This indicates that Sleman has a large number of territories and residents belonging to the disaster-prone areas of Mount Merapi. The high risk of Mount Merapi eruption disaster requires a good disaster management system so that can be handled quickly and accurately. One of the most important is related to disaster management logistics system. After conducting interviews in Cangkringan sub-district, there are two villages affected, namely Kepuharjo and Glagaharjo. Residents complained about humanitarian aid in the effort to overcome the eruption of Merapi eruption in 2010. Complaints that often expressed complaints about the delay in logistics delivery which often reaches 2 to 3 days, the supply of humanitarian aid is still lacking, the type of humanitarian aid needed sometimes not in accordance with the distributed, and bureaucratic and informational discrepancies so that people are confused in getting information.

Head of the disaster logistics division of the Regional Disaster Management Agency (BPBD) Sleman in the interview stated that in the eruption of Merapi 2010, BPBD Sleman has not been formed, so there is no clear coordination on disaster logistics at that time. Humanitarian aid from the government and other parties etc are channeled directly to the point of refuge that is also not well recorded. This has led to miscoordination in the delivery of aid resulting in delays, incompatibilities and uneven supply of relief supplies for victims of the 
eruption of Mount Merapi .Currently BPBD already has one warehouse at the location of the Operations Control Center (Pusdalops), Pakem which began operating from 2015 ago. Nevertheless the BPBD still feel the warehouse is not sufficient because of the problem of access road to the barracks. The results of the interviews indicate that the existing warehouse for humanitarian aid in Merapi is still insufficient in number and in spreading that is feared will cause constraints during the emergency response situation.

Based on the conditions and problems above this research intends to help design the location of the logistics warehouse of Mount Merapi eruption victims. Determination of warehouse location will use the principle of Center of Gravity ( $\mathrm{CoG})$. $\mathrm{CoG}$ is often also called cluster analysis because the center of the cluster works as the center of gravity [12]. Ref. [13] used cluster analysis to determine the location of the additional distribution center. This method is used in determining the potential location of the emergency warehouse of flood disaster based on the distance and demand located in the affected area in Sleman District. It is expected that this research will be able to increase the preparedness in facing disaster especially eruption of Mount Merapi. Mount Merapi eruption emergency response logistics system can respond to the situation in the field on time, precise target, and exact number and can be used as a pilot for other regions in Indonesia. This study aims to determine the number and location of the HAD of Sleman disaster that can reach all evacuation sites. Determination of warehouse location is limited by regulation of BPBD of Sleman Regency.

\section{Research Methods}

Data collection techniques in this research as follows:

1) Secondary data obtained from the literature study in accordance with the material of the problems studied.

2) Preliminary interview addressed to the people affected by the eruption of Mount Merapi in Sleman Regency about humanitarian aid at Mount Merapi eruption in 2010.

3) Direct observation of the object under study that is vulnerable areas of eruption of Merapi in Sleman regency, Central Java.

4) Interview with the Regional Disaster Management Agency of Sleman Regency is related to research on Merapi Eruption disaster mitigation in Sleman District.

The purpose of this first decision is to determine the number and location of HAD needed to ensure that the location and needs of each Distribution Point (DP) can be affordable. The location of HAD will be determined using CoG method. The coordinate data of all DP will be used to determine the location of the HAD where the previously obtained coordinates in the form of degree minute second (DMS) will be converted into decimal degrees (DD). Coordinate data along with the relief goods needs information of each barrak are then used as the basis for calculation. HAD location determination is done by determining CoG from all DP in a cluster. By using two nearest DP locations as CoG, the euclidean distance of two DP location points can be calculated by eq. (1) follows:

$$
D=k \sqrt{\left(x_{i}-x_{j}\right)^{2}+\left(y_{i}-y_{j}\right)^{2}}
$$


Where: $x_{i}$ is coordinate $\mathrm{x}$ at DP location $i, x_{j}$ is coordinate $\mathrm{x}$ at DP location $j, y_{i}$ is coordinate $\mathrm{y}$ at DP location $i, y_{j}$ is coordinate $\mathrm{y}$ at DP location $j$, D is distance of location of DP $i$ and DP $j$ and $\mathrm{k}$ is scale used

From the total DP in the cluster then a pair of DP with the nearest euclidean distance is selected for then determined the location of CoG point whicht is calculated by eq. (2) and (3).

$$
\begin{aligned}
& x_{c}=\frac{\left(x_{i} \cdot d_{i}\right)+\left(x_{j} \cdot d_{j}\right)}{d_{i}+d_{j}} \\
& y_{c}=\frac{\left(y_{i} \cdot d_{i}\right)+\left(y_{j} \cdot d_{j}\right)}{d_{i}+d_{j}}
\end{aligned}
$$

Where: $d_{i}$ is number of demand DP $i, d_{j}$ is number of demand DP $j, x_{c}$ is coordinate $\mathrm{x}$ of $\mathrm{CoG}$ and $y_{c}$ is coordinate $\mathrm{y}$ of $\mathrm{CoG}$

After the coordinate points of $\mathrm{CoG}$ are obtained, the coordinate values can be used to replace the coordinate points of DP 1 and DP 2 that have been combined, eliminate the two DPs and combine them into one CoG. Repeating iterations is done until 1 location is reached as HAD on the cluster. At each iteration the coordinate points on the two adjacent DPs in the previous iteration and have been combined are replaced by the coordinate values of the CoG obtained. Similarly, the need for the DP is then accumulated with the second pair of DP. Iteration continues until a condition where there is no DP or $\mathrm{CoG}$ that can be combined with other entities. Then the coordinate value for HAD to be opened is the point CoG obtained at the last iteration. The selected CoG point will then be matched to the coordinate information of the potential HAD potential candidate choice which will then be the location of the HAD's construction for the cluster [14].

\section{Results and Discussion}

BPBD Sleman Regency has prepared 36 evacuation sites in the form of barracks, village hall, and other locations that will be used as an evacuation point in case of emergency disaster response eruption of Mount Merapi. The slope of Mount Merapi has several rivers, at the time of the rain after eruption of a mixture of piles of material from the eruption of Mount Merapi and rainwater will flow through the river, this is commonly called the cold lava, if the river is not able to accommodate so that the river will overflow will occur cold lava flood. The cold lava flow is feared will undermine the bridges between regions that will then cut off access to evacuation and distribution of relief goods. As has happened in the previous eruption where there will be several bridges that collapsed due to the cold lava flow eruption of Mount Merapi. The reason is used as the basis by BPBD Sleman in designing the evacuation scheme based on the distribution of watershed as outlined in the Document Plan of the Eruption of Mount Merapi Eruption. For the purpose of distributing the logistical support of the victims, the Sleman district government has prepared 17 potential warehouse location alternatives.

For the process of calculating the location of HAD it is necessary to convert the coordinate information that has been obtained in DMS (Degree Minute Second) format to 
Decimal Degree format. Conversion is done to calculate coordinates of evacuation sites and potential depot locations. This study uses the principle of $\mathrm{CoG}$ in determining the location of the depot or warehouse supporting the needs of evacuation sites. The calculation uses evacuation location information that has been done geo-tags before using the help of global positioning system (GPS) as well as data needs of all refugees at each evacuation location. The calculation of the CoG point which is the midpoint of two or more demand points is not only influenced by distance but also takes into consideration the needs of the two points. Where if one of the demand point has a greater need than the other point then the CoG of the two points will tend to be closer to the point of demand that has greater demand.

Calculation begins by converting coordinate information that has been obtained in DMS to DD format with time conversion calculation. After obtained the decimal value of each coordinate point then the calculation continues by calculating the euclidian distance between DP. After all the distance obtained proceed by choosing the distance between the closest DP. From both DP then calculations are done using eq.(2) and (3) to determine the value of the second CoG DP. The demands of both DPs are then accumulated into one. The new CoG and demand points then substitute the DP's second location for the next iteration. Iteration of the calculation is continued until the condition where there are only two points of the location of the entity in the cluster. CoG results of the last iteration which then selected to be HAD calculation results. The calculation results of HAD locations are shown in Table 1.

Tabel 1. The calculation Results of HAD Location

\begin{tabular}{ccccc}
\hline No. & HAD & \multicolumn{2}{c}{ Coordinate } & Total Demand \\
\hline 1 & HAD 1 & $-7,6872^{\circ}$ & $110,3451^{\circ}$ & 215.941 \\
2 & HAD 2 & $-7,6660^{\circ}$ & $110,4187^{\circ}$ & 90.007 \\
3 & HAD 3 & $-7,6746^{\circ}$ & $110,4521^{\circ}$ & 94.763 \\
4 & HAD 4 & $-7,6642^{\circ}$ & $110,4715^{\circ}$ & 23.278 \\
\hline
\end{tabular}

After obtaining all calculation sites then carried out the determination of the location of HAD development by referring to the potential HAD location previously determined by BPBD of Sleman Regency. HAD calculations are then matched with potential HAD locations that have been provided by BPBD Sleman by selecting the point of potential HAD location closest to potential HAD outcomes. The second cluster HAD calculation result is not used because the second cluster will be served by the Pakem Warehouse Pusdalops which has been established previously. The selected location of the CoG method is only based on coordinates that have not seen the real conditions in the field, so that in making decisions it must consider the feasibility of the location for the HAD to be built, such as easy of access, wide area etc. So that the proposed HAD location in this study is to find the closest location from the selected location which allows the HAD to be built if the location of the $\mathrm{CoG}$ calculation results does not allow the depot to be built. With the result that the location of the proposed HAD is very possible to use.

HAD 1 will serve the needs of 14 evacuation sites namely Barracks of Wonokerto, Barracks of Girikerto, Barracks of Merdikorejo, Barracks of Purwobinangun I, Barracks of Purwobinangun II, Purwobinangun Village Hall, Barracks of Pondok Rejo, Banyurejo Village Hall, Barracks of Sumberrejo, Sumberrejo Village Hall, Barracks of Lumbungrejo, Lumbungrejo Village Hall, Pangukan Tridadi field and Triharjo Youth Center. The potential locations of HAD are Bangunkerto, Margorejo, Donokerto, Margorejo II, Mororejo, Jogokerten, Tambakrejo, Banyurejo, and Tridadi. The location of HAD 1 of the calculation is 
at point -7,6872 south latitude (SL) and 110,3451 east longitude (EL), it is located at Agrowisata Street. The closest location to the calculation location is HAD Trimulyo at Salak Street, Jogokerten, Trimulyo Village. The distance of the selected location from the point of HAD calculation result is $1.1 \mathrm{~km}$, so selected the location of HAD Jogokerten.

The second cluster between Kuning River and Boyong River will be directly served by the Pakem Pusdalops warehouse that has been established previously. This warehouse must be able to serve the logistics needs of six evacuation sites namely Barracks of Hargobinangun, Hargobinangun Village Hall, Barracks of Candibinangun, Shelter Act at Gondanglegi Pakem, Universitas Islam Indonesia Campus Pakem, and Center for Teacher Upgrading of Art Campus. This section will only evaluate the location of Pakem Pusdalops. Pusdalops Pakem is at $-7,6673 \mathrm{SL}$ and $110,4191 \mathrm{EL}$, while location of calculation $\mathrm{CoG}$ for region two is at $-7,6667$ SL and 110,4187 EL. The calculation result is about $286 \mathrm{~m}$ from Pakem Pusdalops location.

The result of HAD location calculation for cluster 3 is at -7,6746 SL and 110,4521 EL, the location is rice field in Kuwang Hamlet. The nearest potential HAD from the field is at Huntap Kuwang HAD, Argomulyo Village, Cangkringan District. The distance from the calculated location with Huntap Kuwang HAD is $650 \mathrm{~m}$. This HAD must serve 12 evacuation sites are Barrack of Kiyaran, Wukirsari Village Hall, Barrack of Plosokerep, Barrack of Brayut, Barrack of Kuwang, Barrack of Umbulmartani, Barrack of Bimomartani, Bimomartani Village Hall, Bimomartani Children Social and Barrack of Tirtomartani.

The calculation of $\mathrm{CoG}$ in the last cluster between Gendol River and Sleman regency get coordinate point -7,6642 SL and 110,4715 EL, this location resides in citizen garden at Dliring Hamlet, Argomulyo Village, Cangkringan Sub-district. There are two potential HADs with a short distance, that are Glagaharjo HAD and Sindumartani HAD. Sindumartani HAD was then chosen due to easier road access and location that is farther from the summit of Mount Merapi. Sindumartani HAD will occupy the cash farm of Sindumartani village located at the boundary of Ngemplak sub-district with Cangkringan. Cluster 4 has four evacuation sites, such as Glagaharjo Village Hall, Barrack of Gayam, Sindumartani Village Hall, and Barrack of Koripan Sindumartani. Comparison of the overall location each Cluster shown in Table 2 
Table 2. Comparison of Overall Location each Cluster.

\begin{tabular}{|c|c|c|c|c|c|c|c|}
\hline $\begin{array}{c}\text { Cluste } \\
\text { r }\end{array}$ & Cal & $\begin{array}{l}\text { ation of } \\
\text { AD }\end{array}$ & HAD Potential Location & & dinates & $\begin{array}{c}\text { Euclidie } \\
n \\
\text { Distance }\end{array}$ & $\begin{array}{c}\text { Real } \\
\text { Distanc } \\
\text { e (km) }\end{array}$ \\
\hline \multirow{9}{*}{1} & \multirow{9}{*}{$\begin{array}{l}- \\
7,687 \\
2\end{array}$} & \multirow{9}{*}{$\begin{array}{l}110,345 \\
1\end{array}$} & Bangunkerto, Turi & $-7,6498$ & $\begin{array}{l}110,344 \\
5\end{array}$ & 4,152 & 6,1 \\
\hline & & & Donokerto, Turi & $-7,6552$ & $\begin{array}{l}110,375 \\
3\end{array}$ & 4,879 & 5,5 \\
\hline & & & Banyurejo, Tempel & $-7,7004$ & $\begin{array}{l}110,287 \\
7\end{array}$ & 6,537 & 10,1 \\
\hline & & & Margorejo, Tempel & $-7,6487$ & $\begin{array}{l}110,340 \\
2\end{array}$ & 4,303 & 6,6 \\
\hline & & & Margorejo, Tempel & $-7,6543$ & $\begin{array}{l}110,338 \\
1\end{array}$ & 3,735 & 7,3 \\
\hline & & & Mororejo, Tempel & $-7,6703$ & $\begin{array}{l}110,317 \\
9\end{array}$ & 3,553 & 7,3 \\
\hline & & & Tambakrejo, Tempel & $-7,6842$ & $\begin{array}{l}110,301 \\
7\end{array}$ & 4,825 & 11,4 \\
\hline & & & Tridadi, Sleman & $-7,7133$ & $\begin{array}{l}110,356 \\
7\end{array}$ & 3,176 & 3,5 \\
\hline & & & Trimulyo, Sleman & $-7,6871$ & $\begin{array}{l}110,354 \\
9\end{array}$ & 1,088 & 2,0 \\
\hline \multirow{5}{*}{3} & & \multirow{5}{*}{$\begin{array}{l}110,452 \\
1\end{array}$} & Purwomartani, Kalasan & $-7,762$ & 110,454 & 9,808 & 11,7 \\
\hline & & & Argomulyo, Cangkringan & $-7,675$ & 110,449 & 0,404 & 0,65 \\
\hline & $\overline{7} \overline{7}, 674$ & & Wukirsari, Cangkringan & $-7,651$ & 110,443 & 2,794 & 3,4 \\
\hline & 6 & & Ngemplak & $-7,711$ & 110,454 & 4,062 & 4,6 \\
\hline & & & Selomartani, Kalasan & $-7,733$ & 110,461 & 6,556 & 8,6 \\
\hline \multirow{2}{*}{4} & - & \multirow{2}{*}{$\begin{array}{l}110,471 \\
5\end{array}$} & Tamanmartani, Kalasan & $-7,735$ & 110,484 & 8,048 & 9,4 \\
\hline & 2 & & Glagaharjo, Cangkringan & $-7,648$ & 110,467 & 1,854 & 2,5 \\
\hline
\end{tabular}

\section{Conclusion}

Based on the regulation of BPBD of Sleman Regency, the amount of disaster humanitarian aid warehouse eruption of Mount Merapi is amounted to 4 units of HAD. Determination of location follow clustering and evacuation scheme that is based on river boundary so that minimize the possibility of broken access because of collapse of bridge caused by cold lava flow. The fourth cluster are the western region between Boyong River and Kuning River, the third area is between Kuning River and Opak River, then between Opak River and Gendol River, and the last region is between Gendol River and the boundary of Klaten Central Java and Yogyakarta Province. The number of HAD to be built amounted to 3 units due to the second area between Boyong River and Kuning River already contain warehouses that have been established previously. The location of the construction of the HAD for the first cluster will be built on Trimulyo, Cluster 3 on Huntap Kuwang, and the last cluster at HAD Sindumartani. 


\section{References}

[1] A. Cozzolino, "Humanitarian Logistics," pp. 5-17, 2012.

[2] R. E. Overstreet, D. Hall, J. B. Hanna, and R. Kelly Rainer, "Research in humanitarian logistics," J. Humanit. Logist. Supply Chain Manag., vol. 1, no. 2, pp. 114-131, 2011.

[3] H. Abidi, S. De Leeuw, and M. Klumpp, "Measuring Success in Humanitarian Supply Chains," Int. J. Bus. Manag. Invent., vol. 2, no. ild, pp. 31-39, 2013.

[4] R. Oloruntoba and R. Gray, "Humanitarian aid: An agile supply chain?," Supply Chain Manag., vol. 11, no. 2, pp. 115-120, 2006.

[5] B. Baki, I. M. Ar, and A. Ofluoglu, Multi-criteria decision analysis model for warehouse location in disaster logistics, vol. 4, no. 2. 2017.

[6] N. Ozturk and B. Kaya, "An artificial neural network approach for the logistics center location selection," Pressacademia, vol. 4, no. 2, pp. 107-115, Jun. 2017.

[7] C. Boonmee, M. Arimura, and T. Asada, "Facility location optimization model for emergency humanitarian logistics,” Int. J. Disaster Risk Reduct., vol. 24, pp. 485-498, 2017.

[8] S. Y. Roh, H. M. Jang, and C. H. Han, "Warehouse location decision factors in humanitarian relief logistics," Asian J. Shipp. Logist., vol. 29, no. 1, pp. 103-120, 2013.

[9] V. Bayram and H. Yaman, "A stochastic programming approach for shelter location and evacuation planning," RAIRO - Oper. Res., no. Hasegawa 2013, 2017.

[10] M. Rekik, A. Ruiz, J. Renaud, D. Berkoune, and S. Paquet, "Humanitarian and Relief Logistics," vol. 54, 2013.

[11] M. I. Zamroni, "Islam dan kearifan lokal dalam penanggulangan bencana di jawa," Berkala, Terbit. Nasional, Badan Bencana, Penanggulangan, vol. 2, no. 1-10, 2011.

[12] S. S. Azab and H. A. Hefny, "Center of Gravity PSO for Partitioning Clustering," arXiv Prepr. arXiv1706.00997, pp. 1-7, 2017.

[13] D. L. Widaningrum, A. Andika, and R. D. J. Murphiyanto, "Cluster analysis for determining distribution center location,” IOP Conf. Ser. Earth Environ. Sci., vol. 109, p. 12021, Dec. 2017.

[14] Ballou, R. H.: Business Logistics: Supply Chain Management, Prentice Hall, New Jersey (2003) 